\title{
Executive Environmental Law
}

\author{
Elizabeth Fisher*
}

Accepted for publication in the Modern Law Review (2019)

From the Wiley Licence: 6 months after publication you may post an electronic version of the Article on your own personal website, on your employer's website/repository and on free public servers in your subject area. Electronic versions of the accepted Article must include a link to the published version of the Article together with the following text: 'The definitive version is available at www.wileyonlinelibrary.com'.

Abstract: The Draft (Principles and Governance) Bill published by DEFRA in late 2018 is part of a process of reimagining environmental law in light of Brexit. The Draft Bill creates frameworks for policy statements on environmental principles and environmental implementation plans, as well as creating a new enforcement body - the Office for Environmental Protection. This Draft Bill, at the very least is an ineffectual response to the challenges of environmental law post-Brexit. More alarmingly, it raises the possibility of a legal future in which the executive dominates how the norms, ambitions, and accountabilities of environmental law are defined. These are matters of concern for environmental and public lawyers alike.

Keywords: Environmental Law, Brexit, Legislation, Draft Environment (Principles and Governance) Bill, Constitutionalism

* Professor of Environmental Law, Faculty of Law, University of Oxford, liz.fisher@1aw.ox.ac.uk. I would like to thank Roderick Bagshaw, Sanja Bogojević, Mark Freedland, Ben Pontin, Eloise Scotford and two anonymous reviewers for comments on a previous draft. Any errors or omissions remain my own. 
In a speech in July 2017, the Secretary of State for Environment, Food and Rural Affairs of the United Kingdom, Michael Gove stated in regards to Brexit and environmental protection, that 'in this unfrozen moment new possibilities occur'. ${ }^{1} \mathrm{He}$ is not alone in thinking this. Whatever one thinks of Brexit and whatever comes of it (which at the time of writing is still unclear), the 2016 Referendum catalysed discussion not just about how to replace the legal processes that no longer apply on leaving the EU, but also how leaving leads to 'new possibilities' for UK law and government. Given the significant role that the EU has played in environmental protection, it is natural that environmental law has been a specific focus of this debate. ${ }^{2}$

It has also been an area where 'new possibilities' are in the process of becoming new realities. In January 2018, the Department of Environment, Food and Rural Affairs (DEFRA) put forward a vision for a 'Green Brexit' ${ }^{3}$ in a range of policy documents. In late December 2018, they published the Draft Environment (Principles and Governance) Bill (hereafter the Draft Bill). ${ }^{4}$ The Draft Bill, along with the associated documentation,

\footnotetext{
${ }^{1}$ Michael Gove, 'The Unfrozen Moment - Delivering A Green Brexit' (Speech, 21 July 2017), https://www.gov.uk/government/speeches/the-unfrozen-moment-delivering-a-
} green-brexit accessed 10 Feb 2019.

${ }^{2}$ Eg Robert Lee, 'Always Keep a Hold of Nurse: British Environmental Law and Exit from the European Union' (2017) 29 JEL 155.

${ }^{3}$ DEFRA, A Green Future: Our 25 Year Plan to Improve the Environment (Jan 2018). 4 The documentation for the Bill can be found at https://www.gov.uk/government/publications/draft-environment-principles-andgovernance-bill-2018 accessed 12 Feb 2019. 
is a dramatic imagining a 'new' framework for environmental protection. The Draft Bill, Gove tells us in the Foreword, 'will establish a robust new system of green governance'. 5 The goals, the Prime Minster states, are simple: 'cleaner air and water; plants and animals which are thriving; and a cleaner, greener country for us all'. ${ }^{6}$ In the policy paper accompanying the Draft Bill it is pronounced that the 'Bill will put environmental ambition and accountability at the very heart of government'. ${ }^{7}$ A regular refrain is that different aspects of this approach are 'world-leading'. ${ }^{8}$

This rhetoric is deeply appealing, particularly in regards to a Cinderella subject like environmental protection that rarely gets the priority it should. ${ }^{9}$ But even at its most innocuous, the Draft Bill is unlikely to deliver on these stirring aspirations. This is because it does not create a robust legal framework for 'green governance', accountability, or environmental quality. More worryingly, the Draft Bill has the potential to usher in a legal future in which there is a presumption that the executive dominates how the norms, ambitions, and accountabilities of environmental law are defined. It is a

\footnotetext{
${ }^{5}$ DEFRA, Draft Environment (Principles and Governance) Bill (December 2018) 3.

${ }^{6}$ Prime Minster, 'Foreword' in DEFRA, A Green Future (n 3$) 4$.
}

7 DEFRA, Environmental Bill: Policy Paper (December 2018), https://www.gov.uk/government/publications/draft-environment-principles-andgovernance-bill-2018/environment-bill-policy-paper accessed 18 February 2019.

${ }^{8}$ Eg Ibid, and DEFRA Draft Bill (n 5) 3. DEFRA, A Green Future (n 3) contains 14 examples of the use of the term.

\footnotetext{
${ }^{9}$ See the response of Professor Andrew Jordan in Environmental Audit Committee, The Government's 25 Year Plan for the Environment (HC 803, 2018) 7.
} 
legal future in which ironically law and public reason have potentially little of a role to play. More significantly, the Draft Bill is inadequate in its engagement with the nature of environmental problems, the benefits of legislation, and the importance of constitutionalism. In this 'unfrozen moment' thus lies a risky post-Brexit future - a future that not only environmental lawyers, but also public lawyers should be alert to.

This article is structured as follows. First, I consider the background to the Draft Bill. Second, I examine the Draft Bill itself. Third, I evaluate the Draft Bill and in doing so identify the challenges involved in assessing legislative reform in times such as these. In the final section, by exploring the Draft Bill's inadequacies, I also identify some touchstones for a more constructive way of engaging with this 'unfrozen moment'.

Three points should be made before starting. First, this article may appear premature. At the time of writing (late March 2019), the Draft Bill is not even a Bill. While it is being subject to pre-legislative scrutiny, ${ }^{10}$ it is not yet a formal legislative proposal. Moreover, DEFRA states that the Draft Bill is to be followed by another bill, ${ }^{11}$ albeit has given no details on what that second bill will entail. But even at this stage, a troubling template for the future of environmental law and public law is emerging. It is a template that has potentially serious adverse consequences for both areas of law and it is important that this is highlighted. This Draft Bill is not just creating substitutes for EU institutions and processes, but is an act of reimagining government.

\footnotetext{
${ }^{10}$ Both by the House of Commons Environment, Food and Rural Affairs, Committee and Environmental Audit Committee.

${ }^{11}$ DEFRA, Draft Bill (n 5) 5.
} 
Second, this article is not an exhaustive account of the Draft Bill. It focuses primarily on it as a form of legal architecture. The article also builds on the many important contributions that environmental law scholars ${ }^{12}$ and other bodies ${ }^{13}$ are making to the Brexit environmental law debate. As I conclude, law-makers need to draw more on that work. This article does not also cover the numerous statutory instruments in relation to environmental protection that are being passed pursuant to the statutory instrument

${ }^{12}$ Eg Ben Pontin, The Environmental Case for Brexit (Oxford: Bloomsbury 2019); Lee (n 2); Colin Reid, 'Brexit and the Future of UK Environmental Law' (2016) $34 \mathrm{~J}$ of Energy and Natural Resources Law 407; Chris Hilson, 'The Impact of Brexit on the Environment: Exploring the Dynamics of a Complex Relationship' (2018) 7 TEL 89; Maria Lee, 'Brexit and Environmental Protection in the United Kingdom: Governance, Accountability and Law Making' (2018) 36 J of Energy and Natural Resources Law 351; Helena Howe and Malcom Ross, 'Brexit's Shades of Green-(Missing) the Opportunity to Transform Farming in England?' (2019) 31 JEL (advance access); and Maria Lee, 'The Next Generation of Environmental Law: Environmental Accountability and Beyond in the Draft Environment (Principles and Governance) Bill (London: UCL European Institute Brexit Insights Paper, March 2019).

${ }^{13}$ For example, see the reports of the UK Environmental Law Association (UKELA) Brexit Taskforce. https://www.ukela.org/brexitactivity accessed 19 February 2019 and the House of Commons Environmental Audit Committee (EAC), https://www.parliament.uk/business/committees/committees-a-z/commonsselect/environmental-audit-committee/ accessed 19 February 2019. 
processes under the European Union (Withdrawal) Act 2018. ${ }^{14}$ The executive dominated nature of those processes has also attracted scholarly attention, ${ }^{15}$ but there is little in the Draft Bill and its surrounding documentation concerning these statutory instruments.

Third, devolution is an important part of the structure of environmental law in the UK. Much, albeit not all of the Bill, primarily pertains to England. ${ }^{16}$ and devolved functions are excluded from some of its scope. ${ }^{17}$ Scotland and Wales have also taken, or are taking, reform steps to reconfigure their environmental laws in light of Brexit ${ }^{18}$ This $^{2}$

14 Section 8 and Schedule 7. As of the 27 March 2019, DEFRA has laid 118 Brexit statutory instruments, https://www.hansardsociety.org.uk/blog/westminster-lens-brexitstatutory-instruments-dashboard\#how-many-brexit-statutory-instruments-does-thegovernment-plan-to-lay-before-parliament accessed 27 March 2019.

${ }^{15}$ Paul Craig, 'Constitutional Principle, the Rule of Law and Political Reality: The European Union (Withdrawal) Act 2018 ' (2019) 82 MLR 319 and Mark Elliott and Stephen Tierney, 'Political Pragmatism and Constitutional Principle: The European Union (Withdrawal) Act 2018' [2019] PL 37.

${ }^{16}$ EAC (n 9) 4, 28. DEFRA, Environmental Principles and Governance after the United Kingdom Leaves the European Union: Consultation on Environmental Principles and Accountability for the Environment (May 2018) Foreword.

${ }^{17} \mathrm{Eg} \mathrm{Cls} \mathrm{6(7),} \mathrm{17(3)}$

${ }^{18}$ Scottish Government, Environmental Governance in Scotland on the UK's Withdrawal from the EU (July 2018); Scottish Government, Consultation On Environmental Principles And Governance in Scotland (February 2019); and Victoria Jenkins ‘Sustainable Management of Natural Resources: Lessons from Wales' (2018) JEL 399. 
article does not cover these developments, but I would encourage readers to look at those proposals to see different ways of imagining environmental law futures.

\section{Brexit and the Environmental Law Imagination}

Environmental problems are collective action problems. ${ }^{19}$ Such problems, and the responses to them, are inevitably contentious. They require choices to be made about what is an acceptable and unacceptable impact on the environment and whose activities must be curtailed or adjusted to deal with those impacts. ${ }^{20}$ The collective action nature of environmental problems inevitably requires state action to address them. In national regimes, for this action to be legitimate it requires involvement from all arms of government - the legislature, the executive/public administration, and the courts. Such

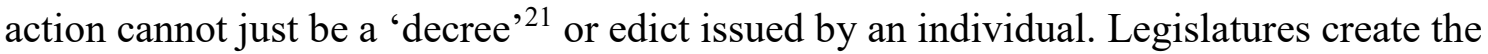
mandates and frameworks for public action. ${ }^{22}$ The executive and administration are the

${ }^{19}$ Garrett Hardin, 'The Tragedy of the Commons' (1968) 162 Science 1243.

${ }^{20}$ Consider for example the environmental disputes at the heart of these different recent Supreme Court cases: Coventry v Lawrence [2014] UKSC 13 (noise from a raceway affecting a residential house); Walton $v$ Scottish Minsters [2012] UKSC 44 (environmental impacts of a transport infrastructure project; Dover DC $v$ CPRE (Kent) [2017] UKSC 79 (housing development impacting on an Area on Outstanding Natural Beauty);

${ }^{21}$ Jeremy Waldron, The Rule of Law and the Measure of Property (Cambridge: CUP, 2012) 107

${ }^{22}$ Eloise Scotford and Jonathan Robinson, 'UK Legislation and Its Administration in 2013 - Achievements, Challenges and Prospects' (2013) 25 JEL 383. 
site for the operation of those frameworks. ${ }^{23}$ Given the substantive discretion that involves, the courts have an important role in reviewing administrative action for errors of law. ${ }^{24}$ As environmental issues are contentious, courts also play an important dispute settlement function. ${ }^{25}$

Given that the law did not traditionally address polycentric, dynamic, and scientifically uncertain environmental problems, environmental problems have required the exercise of legal imagination in creating legislative and other legal frameworks ${ }^{26}$ This $^{2}$ has included legal frameworks that create markets ${ }^{27}$ and dictate forms of scientific assessment. ${ }^{28}$ Environmental law may be novel but it still must be consistent with legal

${ }^{23}$ Keith Hawkins, Environment and Enforcement: Regulation and the Social Definition of Pollution (Oxford: Clarendon Press, 1984).

${ }^{24}$ Richard Moules, Environmental Judicial Review (Oxford: Hart, 2011). See also Ole Pedersen, 'A Study of Administrative Environmental Decision-Making before the Courts' (2019) 31 JEL advance access.

${ }^{25}$ Elizabeth Fisher, Eloise Scotford, and Emily Barritt, 'The Legally Disruptive Nature of Climate Change' (2017) 80 MLR 173, 197.

${ }^{26}$ Elizabeth Fisher, Environmental Law: A Very Short Introduction (Oxford: OUP, 2017)

Ch 5 .

${ }^{27}$ Sanja Bogojević, Emission Trading Schemes: Markets, States, and Law (Oxford: Hart, 2013).

${ }^{28}$ Jane Holder, Environmental Assessment: The Regulation of Decision Making (Oxford: OUP, 2004). 
principles such as the rule of law and other public law doctrines. ${ }^{29}$ Law and legal reasoning is ensuring stability. ${ }^{30}$ Given all this, in most Western jurisdictions, environmental law is a dense thicket of legislation, administrative action, and judicial decisions that is embedded into a legal culture.

\subsection{The EU Referendum and Environmental Protection}

The essential picture is no different in the UK. There is a detailed body of legislation, delegated legislation, administrative regimes, and a large body of legal doctrine generated by the courts. ${ }^{31}$ Engaging with UK environmental law requires an engagement with the many different facets of UK legal culture including its many national, local and devolved institutions, different forms of law-making, and a range of regulatory and policy styles. ${ }^{32}$

With that said, the EU has dominated the legal substance and legal imagination of UK environmental law. The EU, sometimes using UK regulation as inspiration, ${ }^{33}$ has set many of the standards and techniques of environmental law and provided significant legal

${ }^{29} \mathrm{Eg}$ HS2 Action Alliance Ltd, $R$ (on the application of) $v$ The Secretary of State for Transport [2014] UKSC 3 and Mott, $R$ (on the application of ) $v$ Environment Agency [2018] UKSC 10.

${ }^{30}$ Bruno Latour, The Making of Law: An Ethnography of the Counseil D'état (Cambridge: Polity Press, 2010) 243.

${ }^{31}$ Elizabeth Fisher, Bettina Lange, and Eloise Scotford, Environmental Law: Text, Cases and Materials (2 $2^{\text {nd }}$ ed, Oxford: OUP, 2019).

32 ibid, Chapter 10 and Pontin (n 12).

${ }^{33}$ Hilson (n 12) 93-4 
rights and structures for accountability and dispute resolution. ${ }^{34}$ Much of this has to do with the timing of the UK's entry into the European Economic Community (EEC). The UK does have a long history of what we would now call 'environmental legislation', ${ }^{35}$ but it was only in the 1970s, as in most other Western jurisdictions, that environmental protection began to cohere into a comprehensive area of government activity. With EEC membership in 1972, nascent national debates about environmental protection quickly became side-lined by wider EEC debates. This was because the EEC from the early 1970s onwards developed a comprehensive and ambitious body of environmental law. The catalysts for these developments were 'common market' building and an explicit desire to develop an environment protection programme. ${ }^{36}$

A distinct British environmental law discourse did continue after 1972 and British environmental lawyers did engage with 'big' questions of enforcement, ${ }^{37}$ adjudication, ${ }^{38}$

${ }^{34}$ Maria Lee (n 12) and Maia Perraudeau, 'Back to the Future: Brexit, EIA and the Challenge of Environmental Judicial Review' (2019) 21 Env L Rev 6.

${ }^{35}$ Pontin (n 12).

${ }^{36}$ Albert Weale and others, Environmental Governance in Europe: An Ever Closer Ecological Union? (Oxford: OUP, 2002).

37 Richard Macrory, Regulatory Justice: Making Sanctions Effective: Final Report (November 2006).

38 Malcolm Grant, Environmental Court Project: Final Report (Department of Environment, Transport and the Regions, 2000) and Lord Carnwath, 'Judges and the Common Laws of the Environment-At Home and Abroad' (2014) 26 JEL 177. 
and legislative reform. ${ }^{39}$ But they never did so on purely British terms and there was never the opportunity to reckon with questions about the overall nature of environmental law. While other Commonwealth jurisdictions experimented with comprehensive packages of environmental law reform, ${ }^{40}$ the UK did not. Moreover, British engagement with environmental law issues was often responsive to EU developments. Overall, imagining what was possible in British environmental law was always shaped by EEC, then EC, then EU membership.

Given this, the EU referendum was inevitably momentous from an English environmental law perspective. Most immediately there was a concern of how to ensure environmental protection standards would be maintained. This was particularly when much of Brexit rhetoric was about removing regulatory red tape. ${ }^{41}$ The Environment Audit Committee (EAC) in January 2017 argued in The Future of the Natural Environment after the EU Referendum that there was a need for a 'new Environmental Protection Act, ensuring that the UK has an equivalent or better level of environmental protection as in the EU'. ${ }^{42}$ The European Union (Withdrawal) Act 2018, passed in June

${ }^{39}$ UKELA, The State of Environmental Law 2011-2012: Is There a Case for Legislative Reform (2012) and Scotford and Robinson (n 22).

${ }^{40}$ Eg Resource Management Act 1991 (New Zealand); Land and Environment Court Act 1979 (New South Wales); and Environmental Planning and Assessment Act 1979 (New South Wales).

${ }^{41}$ Hilson (n 12) 94-5

${ }^{42} \mathrm{EAC}$, The Future of the Natural Environment after the EU Referendum (HC 599, 2017) 4. 
2018, went a long way to addressing this issue by effectively making EU law, national law. ${ }^{43}$

It also became quickly evident that Brexit presented structural questions for environmental law. As Maria Lee puts it, Brexit means 'we need to replace the dense and extensive governance and legal framework that enhances the legal and political accountability of government and government bodies ${ }^{44}$ in regards to environmental obligations. She cites direct effect and the Commission's enforcement and oversight powers, both disappearing with Brexit, as being particularly important. Few would disagree. There was also concern that environmental law would become a field of unenforced 'zombie legislation'. ${ }^{45}$ As the EAC described it, zombie legislation is 'EU legislation transposed into UK law which is no longer updated and which can be eroded through statutory instruments with minimal parliamentary scrutiny'. ${ }^{46}$ What these concerns highlight is that EU environmental law does not just provide the standards and strategies of environmental law but also the means of enforcement and holding decisionmakers to account. In doing so a rich body of UK and EU case law exists which does not just enforce the law, but also interprets it and gives environmental law obligations substantive meaning. ${ }^{47}$

${ }^{43}$ Sections 2 and 3.

${ }^{44}$ Maria Lee (n 12) 351.

${ }^{45}$ EAC, The Future of the Natural Environment (n 42) 3.

${ }^{46}$ Ibid 3.

${ }^{47} \operatorname{Eg} R$ (on the application of ClientEarth) $v$ Secretary of State for the Environment, Food and Rural Affairs [2015] UKSC 28; C-127/02 Landelijke Vereniging tot Behoud van de 
The European Union (Withdrawal) Act 2018 is also an attempt to address this by including Section 16. That section requires two things. First it requires the Secretary of State, 'within the period of six months beginning with the day on which this Act is passed, to publish a draft Bill consisting of a set of environmental principles' and imposes a duty on him 'to publish a statement of policy in relation to the application and interpretation of those principles in connection with the making and development of policies by Ministers of the Crown'. Section 16(2) lists the relevant environmental principles which include principles that can be found in Articles 11 and 191(2) TFEU and which have given rise to a rich body of case law and practice. ${ }^{48}$ It also includes the three 'principles' that are the three pillars to the UNECE Convention on Access to Information, Public Participation in Decision-making and Access to Justice in Environmental Matters. ${ }^{49}$ Second, section 16(1)(d) requires the Bill to include "provisions for the establishment of a public authority with functions for taking, in circumstances provided for by or under the Bill, proportionate enforcement action (including legal proceedings if necessary) where the authority considers that a Minister of the Crown is not complying with environmental law (as it is defined in the Bill)'.

Section 16 is the primary catalyst for the Draft Bill, but it is not the only influence. As Gove's reference to the 'unfrozen moment' highlights, debate about the future of environmental law did not remain focused on just replacing EU legal mechanisms. As

Waddenzee v Staatssecretaris van Landbouw [2004] ECR I-7405; Berkeley v. Secretary of State for The Environment and Others [2001] 2 AC 603

${ }^{48}$ Eloise Scotford, Environmental Principles and the Evolution of Environmental Law (Oxford: Hart, 2017) Ch 4.

${ }^{49} 2161$ UNTS 447. 
Macrory and Thornton noted in 2017, 'Brexit will at some point provide an opportunity to re-evaluate the existing structure of national environmental law, ${ }^{50}$ This prophecy was quickly a reality.

\subsection{DEFRA's Vision of an Environmental Law Future}

Even before the EU Referendum, the Coalition and Conservative governments were putting forward a new ideal of English environmental law. In 2011, in The Natural Choice: Securing the Value of Nature, HM Government stated that 'We will put natural capital at the centre of economic thinking and at the heart of the way we measure economic progress nationally' ${ }^{51}$ The Natural Capital Committee (NCC) was created the next year to provide advice. ${ }^{52}$ The 2015 Conservative Manifesto set the goal that this would be 'the first generation to leave the natural environment in a better state that that in which we found it'.53

After the EU Referendum, a more distinct picture emerged of the reforms that would follow through on these commitments. In January 2018, DEFRA, with strong encouragement from the NCC, published A Green Future: Our Twenty Five Year Plan to

${ }^{50}$ Richard Macrory \& Justine Thornton, 'Environmental Principles: Will They Have a Legal Role After Brexit?' [2017] JPEL 907, 913.

${ }^{51}$ HM Government, The Natural Choice: Securing the Value of Nature (CM 8082 2011)

4.

52 https://www.gov.uk/government/groups/natural-capital-committee accessed 19 February 2019.

${ }^{53}$ UK Conservative Party, The Conservative Manifesto 2015, 54. 
Improve the Environment (25 Year Plan). ${ }^{54}$ That plan is strong on ambition. The Plan has its aspiration 'delivering a Green Brexit'. ${ }^{55}$ It is described as a 'living blueprint'. ${ }^{56}$ There are three important features of the Plan to note.

The Plan emphasises targets. The Plan has six environmental quality goals and four pressures that are to be minimised, as well as stating that over 200 measurable actions will be taken. ${ }^{57}$ The Government has described these actions as a mixture of 'specific, time bound outputs' and 'radical areas of policy reform which will take some time to develop'. ${ }^{58}$ This emphasis on targets can be understood as directly responding to the Conservative Manifesto's aim for environmental improvement as well as concerns that Brexit will result in the lowering of environmental standards. By meeting these targets, the thinking goes, the Manifesto's aims will be met and standards will not be lowered. Further work is being done to develop indicators so as to make the targets measurable. ${ }^{59}$ There are criticisms of these targets. The EAC notes the Plan 'lacks details on how these

\footnotetext{
${ }^{54}$ DEFRA, A Green Future (n 3).
}

55 ibid 9.

56 ibid 11.

57 The Government's 25 Year Plan for the Environment: Government Response to the Committee's Eighth Report: Twelfth Special Report of Session 2017-9 (HC1672 2018) 4. 58 ibid 2.

${ }^{59}$ DEFRA, Measuring Environmental Change - Draft Indicators Framework for the 25 Year Environment Plan - Draft for Discussion (December 2018) https://www.gov.uk/government/consultations/25-year-environment-plan-measuringprogress accessed 24 February 2019. 
objectives will be achieved' ${ }^{60}$ Likewise, the NCC has argued that the Plan needs better and more appropriate indicators. ${ }^{61}$

The second aspect of the 25 Year Plan focuses on the related idea of accountability. Again, this addresses the concerns about the loss of accountability that Brexit will bring. ${ }^{62}$ While there is not much detail on accountability in the Plan, what there is, characterises it as a process by which there is reporting 'of progress against our [DEFRA's] new metrics'. ${ }^{63}$ It involves 'thorough oversight against the Plan'64 and requires a more co-ordinated approach where 'local areas are mapped and managed more as a system, with a "system operator" responsible for strategic management of the natural capital' ${ }^{65}$ Accountability is closely aligned with the concept of governance but there is relatively little detail on what governance actually means. ${ }^{66}$ 'Natural capital' is the

${ }^{60}$ EAC, The Government's 25 Year Plan (n 9) 3.

${ }^{61}$ Natural Capital Committee, State of the Natural Capital Annual Report 2019 (Sixth Report to the Economic Affairs Committee of the Cabinet) 17. See also the National Audit Office, Environmental Metrics: Government's Approach to Monitoring the State of the Natural Environment (January 2019).

${ }^{62}$ DEFRA, A Green Future (n 3) 7, 11, 24, 128, 139.

${ }^{63}$ Ibid, 138. See also EAC, The Government's 25 Year Plan (n 9) 7 for Gove's description of accountability in these terms.

${ }^{64}$ DEFRA, A Green Future (n 3) 139.

65 ibid 140. DEFRA, Measuring Environmental Change (n 59) 3.

${ }^{66}$ A common criticism seen in EAC, The Government's 25 Year Plan (n 9) 6, 8, 10. 
primary language of this accountability. ${ }^{67}$ The Plan is described as 'government-led' but it makes clear that 'everyone in society must play their part'. ${ }^{68}$ In a speech in June 2018 , Michael Gove stated that '[i]n order to ensure we properly value, and benefit from, the growth in natural capital we need to develop our economic models to marry the innovation that only the market can provide to the moral purpose of environmental enhancement'. 69

The third aspect of the Plan to note is that it is silent when it comes to law, legal reasoning and legal institutions. Given the Plan is a policy document that is perhaps not surprising, except that the main implications of leaving the EU are legal implications. ${ }^{70}$ Reading the Plan, you could be forgiven for thinking that a complex body of environmental law did not exist. DEFRA talks about 'measures' that have resulted in cleaner waters and cleaner air ${ }^{71}$ - but says nothing substantive about the history of environmental legislation. They note:

This progress is the result of many different policies, plans, Commissions, commitments and regulations and we are grateful to the vital players who have

${ }^{67}$ DEFRA, A Green Future (n 3) 24, 27, 34, 139, 140.

68 ibid 11, 20, 22.

${ }^{69}$ Michael Gove, 'The Right Environment for Growth- Reforming Capitalism for the $21^{\text {st }}$ Century' (Speech for Policy Exchange, 8 June 2018) 9. See also Gove, 'The Unfrozen Moment' (n 1).

${ }^{70}$ Compare with EAC, The Future of the Natural Environment (n 42).

${ }^{71}$ DEFRA, A Green Future (n 3) 21, 
contributed; our farmers, fishers, businesses, and environmental and conservation groups among many others. ${ }^{72}$

Law is rarely mentioned in the document. References are to international law or putting in place the idea of conservation covenants. ${ }^{73}$ The hope is that EU environmental law 'continues to hold sway in the UK' ${ }^{74}$ There is no mention of UK courts in the Plan and little mention of the fact that many of the actions needing to be taken will require some form of law. Emphasis is placed on needing to read the plan in line with other strategies ${ }^{75}$ and the need to create other strategies. ${ }^{76}$

The Plan also presents a very disembodied vision of 'governance'. There is minimal discussion of the institutions of English government except in the abstract. As noted in the introduction, the language of 'world leading' is constantly used ${ }^{77}$ which reads as if there is a hope this model of governance can be transplanted to other places. A flipside of it being so, is that is seemingly not attached a legal culture or to culture at all. ${ }^{78}$

\footnotetext{
72 ibid 22.

73 ibid 57, 62, 148.

${ }^{74}$ ibid 129.

75 ibid 6, 11, 16, 18,48, 51, 107,108

${ }^{76}$ ibid $12,13,25,26,45,100$

77 (n 8).
}

78 Bruno Latour, Down to Earth (Cambridge: Polity Press, 2018) discussing the disembodied nature of global views. 


\subsection{Other Environmental Law Futures}

DEFRA is not the only institution that has been reimagining environmental law in the UK. Even before the EU Referendum conversations about the future trajectory of law in this area were taking place. In Wales there was a dramatic legislative reconfiguring of environmental law. ${ }^{79}$ In the UK, there has also been discussion about the need for specialist environmental adjudicators. ${ }^{80}$ In 2012, the UK Environmental Law Association (UKELA) argued the need for lawyers to give more attention to the quality of environmental legislation. ${ }^{81}$

After the shock of the Referendum subsided, scholars and others also began to envision different possibilities for UK environmental law. ${ }^{82}$ Some grounded their analysis in environmental law thought, ${ }^{83}$ others in engagement with legal reasoning and legal

\footnotetext{
${ }^{79}$ Jenkins (n 18).
}

${ }^{80}$ For an overview of these developments see Richard Macrory, 'The Long and Winding Road-Towards an Environmental Court in England and Wales' (2013) 25 JEL 371.

${ }^{81}$ UKELA, The State of Environmental Law (n 39)

82 (n 12) and Elizabeth Fisher and James Harrison, 'Beyond the Binary: Brexit,

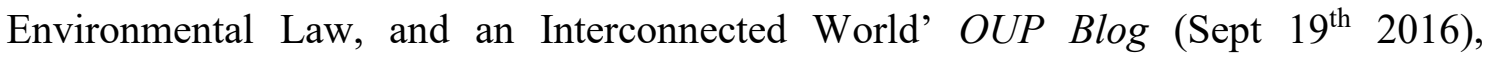
https://blog.oup.com/2016/09/binary-brexit-environmental-law/ accessed 23 February 2019. Also see the Broadway Initiative, Blueprint for an Environment Act (26 November 2018) https://www.iema.net/broadway accessed 22 February 2019.

${ }^{83}$ Howe and Ross (n 12). 
processes, ${ }^{84}$ and others in British legal culture. ${ }^{85}$ There were those that explored the substantive institutional implications and needs of Brexit. ${ }^{86}$ As noted above, the House of Common Environmental Audit Committee (EAC) $)^{87}$ and UKELA ${ }^{88}$ also made substantive contributions to the post-Referendum debate. In the devolved regions, proposals are being debated and explored. ${ }^{89}$

Overall these contributions stand in stark contrast to DEFRA's proposed framework. In them, environmental law is understood as a body of law that needs to be assessed in the context of a wider legal and institutional context. For example, the Scottish Government in their consultation on environmental principles stress not only how environmental principles must be understood in the context of EU law, but if they are put into Scottish law an understanding is needed of how they will interface with other Scottish

${ }^{84}$ Eloise Scotford and Megan Bowman, 'Brexit and Environmental Law: Challenges and Opportunities' (2016) 27 Kings Law Journal 416, 418 and Maria Lee, ‘Accountability for Environmental Standards after Brexit' (2017) 19 Environmental Law Review 89.

${ }^{85}$ Pontin (n 12).

${ }^{86}$ Charlotte Burns and others, 'De-Europeanising or Disengaging? EU Environmental Policy and Brexit' (2019) 28 Environmental Politics 271.

${ }^{87}$ EAC, the Future of the Natural Environment (n 42) and EAC, The Government's 25 Year Plan (n 9).

88 (n 13).

${ }^{89}$ (n 18). 
public law duties. ${ }^{90}$ Commentators have also stressed the importance of legislative consolidation, ${ }^{91}$ dispute resolution, and legal accountability. ${ }^{92}$ UKELA in their report on environmental accountability post-Brexit noted that 'Rather than a single solution for legal accountability the issue is best addressed with a range of mechanisms, of which judicial review would form one element' ${ }^{93}$

In contrast to the dis-embedded model of green governance in the 25 Year Plan, these acts of envisaging environmental law futures in the UK, are all highlighting the significance of UK legal culture. This can also be seen in the initial responses to the Plan and associated policies. For example, Pontin notes that any approach needs to recognise that '[c]omplexity is a defining feature of the British way' of environmental law. ${ }^{94}$ In interpreting section 16 of the European Union (Withdrawal) Act 2018 he understands legal significance in terms of UK constitutional law doctrine. ${ }^{95}$ Likewise, Perraudeau has argued eloquently that ' $[\mathrm{t}] \mathrm{o}$ ensure that the UK has effective environmental law in a postBrexit future it will be important, alongside preparing new institutional arrangements, to look backwards, to more fully understand how UK courts react to environmental

${ }^{90}$ Scottish Government, Consultation on Environmental Principles and Governance (n 18) 8,12 .

${ }^{91}$ Scotford and Bowman (n 83) 419.

${ }^{92}$ Maria Lee, 'The Next Generation of Environmental Law' (n 12).

${ }^{93}$ UKELA, Brexit and Environmental Law: Enforcement and Political Accountability Issues (July 2017) 3.

${ }^{94}$ Pontin (n 12) 12.

95 ibid 136. 
legislation'. ${ }^{96}$ Rodgers, in discussing associated proposals regarding payment for ecosystems services in the agricultural sector, has stressed the importance of 'solid legal foundations' ${ }^{97}$

\section{The Draft Environment (Principles and Governance) Bill}

For most lawyers, the need to ensure that any reforms are consistent with existing legal principles is of such tautological obviousness as to be not worth articulating. But as Freedland has noted of Brexit more generally, there has been a tendency to ignore this tautology. ${ }^{98}$ The 25 Year Plan was followed by a DEFRA Consultation Document on Environmental Principles and Government after the United Kingdom leaves the European Union which was published in May 2018. ${ }^{99}$ That document was the forerunner to the Draft Bill and had a large number of responses. ${ }^{100}$ In that document different

${ }^{96}$ Perradeau (n 34) 20.

${ }^{97}$ Christopher Rodgers, 'Delivering a Better Natural Environment? The Agriculture Bill and Future Agri-environment Policy’ (2019) 21 Env L Rev 38, 48.

${ }^{98}$ Mark Freedland, 'Brexit, the Rule of Law, and the Idea of Sustainable Governance' Oxford Legal Studies Research Paper No. 5/2018, 7, https://papers.ssrn.com/sol3/papers.cfm?abstract id=3117471 accessed 23 February 2019.

${ }^{99}$ DEFRA, Consultation Paper (n 16). For a discussion of this see Ole Pedersen, 'PostBrexit Environmental Accountability and Enforcement - Who is Afraid of the Courts?' (2018) 20 Environmental Law Review 133.

${ }^{100}$ DEFRA, Environmental Principles and Governance After the United Kingdom Leaves the European Union: Summary of Responses and Government Response (December 
accountability mechanisms are recognised, but as a textbook description to accompany the proposals rather than as the proposals. ${ }^{101}$ The emphasis is on 'delivering' environmental law. ${ }^{102}$ It is stated that the UK 'already benefits from a vibrant democracy and robust legal system', ${ }^{103}$ but the implications of this for the Draft Bill are not discussed.

The Draft Bill was published on the 19 December 2018. It has three parts. I consider each below. Each part is significant and the Bill is also more than the sum of its parts. What is also striking to note is the Bill contains no overarching obligation to protect the environment.

\subsection{Policy Statements on Environmental Principles}

The first part of the Draft Bill is an attempt to deliver on section 16(1)(a)-(c) and 16(2) of the European Union (Withdrawal) Act 2018 by creating a framework for the role that environmental principles play in environmental law. ${ }^{104}$ In most other jurisdictions,

2018), $\quad$ https://www.gov.uk/government/consultations/environment-developingenvironmental-principles-and-accountability accessed 23 February 2019.

${ }^{101}$ DEFRA, Consultation Paper (n 16) 17-18.

102 ibid 24, 25,

103 ibid 12.

${ }^{104}$ For an overview see Maria Lee and Eloise Scotford, 'Environmental Principles After Brexit: The Draft Environment (Principles and Governance) Bill' (January 25 2019), https://papers.ssrn.com/sol3/papers.cfm?abstract id=3322341 accessed $22^{\text {nd }}$ Feburary 2019. 
including the EU, ${ }^{105}$ environmental principles are understood as principles with a distinctive and important legal role. ${ }^{106}$ While often included in legislation, they are usually accompanied by administrative elaboration and have been subject to judicial interpretation and application. ${ }^{107}$ The legal significance of environmental principles is also in the context of individual regulatory and judicial decisions. The EU courts have played a role in explicitly applying and interpreting environmental principles and the UK courts have then applied that case law to develop their own doctrines. The application of the precautionary principle to Article $6(3)$ of the Habitats Directive ${ }^{108}$ is a good example of this. ${ }^{109}$ As Scotford has powerfully argued, environmental principles are not so much solutions to environmental problems but catalysts for legal development within a legal culture. $^{110}$

105 T 74/00 Artegodan v Commission [2002] ECR II-4945 and T-392/02 Solvay Pharmaceuticals BV v Council [2003] II-4555.

${ }^{106}$ Scotford (n 48).

${ }^{107}$ Ibid.

${ }^{108}$ Council Directive 92/43/EEC of 21 May 1992 on the conservation of natural habitats and of wild fauna and flora [1992] OJ L206/7.

${ }^{109}$ An example of EU case law is Waddenzee (n 47) and UK case law is Smyth $v$ The Secretary of State for Communities and Local Government [2015] EWCA Civ 174.

${ }^{110}$ Scotford (n 48). 
In the Draft Bill, principles are stripped of this catalytic role. ${ }^{111}$ Rather, principles become devices by which the Secretary of State directs policy-making across government. The Draft Bill requires ${ }^{112}$ the Secretary of State to prepare policy statements that 'must explain how the environmental principles are to be interpreted and proportionately applied by Ministers of the Crown in making, developing and revising their policies'. ${ }^{113}$ Clause 4 provides that Ministers of the Crown 'must have regard to the policy statement on environmental principles when making, developing or revising policies dealt with by the statement' ${ }^{114}$ but they explicitly do not have to take action when taking or not taking action 'would have no significant environmental benefit' or 'would be in any other way disproportionate to the environmental benefit' ${ }^{115}$ There are also a number of other caveats relating to the policy statements and their applications. ${ }^{116}$ The Draft Bill thus limits the application of the policy statements of principles. While as legal principles, environmental principles operate as widely applicable principles of law, the policy statements on principles only operate in specific circumstances.

${ }^{111}$ Note the Bill is accompanied by DEFRA, Information Paper on the Policy Statement on Environmental Principle (December 2018) which explains how they will work as policy statements.

${ }^{112} \mathrm{Cl}(1) 1$.

${ }^{113} \mathrm{Cl} 1(2)$.

${ }^{114} \mathrm{Cl} 4(1)$.

${ }^{115} \mathrm{Cl} 4(2)$

${ }^{116} \mathrm{Cl} 1(5)-(6)$. 
The Draft Bill does set out the process for creating such policy statements. ${ }^{117}$ It does include a duty to consult, but only 'such persons as the Secretary of State considers appropriate in relation to the draft statement'. ${ }^{118}$ The policy statement must be laid before Parliament, but only for 21 days and does not require positive affirmation. ${ }^{119}$ The Bill allows the policy statement to be revised at any time. ${ }^{120}$

The Draft Bill thus does not give legal status to environmental principles per se, as Article 11 and 191(2) TFEU did, but to the s policy statement on the principles. It is that which binds Ministers. What is legally binding is thus what Secretary of State declares environmental principles to be. The overall effect is to vest the Secretary of State with considerable power to dictate major norms of environmental law including access to justice. While courts could still play a role in interpreting these policy statements ${ }^{121}$ and in recognising principles in non-policy contexts, ${ }^{122}$ the Draft Bill makes the substantive nature of environmental principles primarily the province of the executive.

${ }^{117} \mathrm{Cl} 3$.

${ }^{118} \mathrm{Cl} \mathrm{3(2).}$

${ }^{119} \mathrm{Cl} 3(3)-(5)$.

${ }^{120} \mathrm{Cl} 3(6)$.

${ }^{121}$ See for example the Court's engagement with the concept of sustainable development in the National Planning Policy Framework (NPPF). See Suffolk Coastal District Council v Hopkins Homes Ltd [2017] UKSC 37.

${ }^{122}$ Smyth (n 109) relates to a planning decision. 


\subsection{Environmental Improvement Plans}

The second part of the Draft Bill is described in the Draft Bill as making 'provision imposing duties on the Secretary of State for the purpose of seeking to improve the natural environment'. ${ }^{123}$ These duties relate to the preparation and operation of environmental improvement plans (EIPs). This part of the Draft Bill was not required by Section 16 of the European Union (Withdrawal) Act 2018. It can be understood as partly responding to losing the implementation oversight of the Commission ${ }^{124}$ and also a response to the EAC and NCC's calls to place the 25 Year Plan on a 'statutory footing' ${ }^{125}$ It also potentially represents one of the most significant structural reforms that the Draft Bill creates. This is because the Bill gives EIPs a privileged role in articulating the ambitions and goals of environmental law.

An EIP is defined in the Draft Bill as 'a plan for improving the natural environment in the period to which the plan relates'. ${ }^{126}$ The Draft Bill requires that the period must be more than 15 years ${ }^{127}$ and that the 25 Year Plan is the first EIP. ${ }^{128}$ The most significant feature of an EIP is that it acts as the benchmarks which will be used to judge progress. The Secretary of State must lay before Parliament a statement about how

${ }^{123} \mathrm{Cl} 5$.

${ }^{124}$ DEFRA, Consultation Paper (n 16) 17.

${ }^{125}$ EAC (n 9) 5.

${ }^{126} \mathrm{Cl} 6(2)$.

${ }^{127} \mathrm{Cl} 6(3)$.

${ }^{128} \mathrm{Cl} 6(7)$. 
data will be obtained 'for the purpose of monitoring whether the natural environment is ....improving in accordance with the current' [EIP]'. ${ }^{129}$ He must then provide an annual report which considers such data. ${ }^{130}$ The Office for Environmental Protection (OEP) (see Section 2.3) must also monitor and annually report on progress against a current EIP. ${ }^{131}$ Unlike policy statements on environmental principles, EIPs do not directly bind other Ministers of the Crown. Rather, the significance of EIPs is they act as the yardsticks that environmental progress will be assessed by.

Given the 25 Year Plan already exists, the Draft Bill only sets out a process by which EIPs can be reviewed and revised (at least every five years), ${ }^{132}$ as well as a process of renewing an EIP. ${ }^{133}$ Those processes do not involve any duty of consultation, but the Secretary of State must lay before Parliament any revised plan or a statement about why they have not decided to revise it. ${ }^{134}$ In the process of renewing and revising, the Secretary of State must consider what has been done to implement an existing/old EIP; whether there is data from aan nnual or OEP report that the natural environment has improved;

\footnotetext{
${ }^{129} \mathrm{Cl} 7(1)$.

${ }^{130} \mathrm{Cl} 8(2)$. This must be laid before Parliament (Cl 8(6).

${ }^{131} \mathrm{Cl} 14$.

${ }^{132} \mathrm{Cl}$ 9(2)-(3).

${ }^{133} \mathrm{Cl} 10$.

${ }^{134} \mathrm{Cl}$ 9(7)-(8).
} 
and whether Her Majesty's Government should take further action or different steps. ${ }^{135}$ Given the 25 Year Plan already exists, the nature of what is an EIP feels very pre-defined.

The obligations and standards set out in existing legislation would normally be understood as the goals in environmental law to be achieved, but there is no reference in the Draft Bill to how EIPs relate to existing legislation. Turning to the 25 Year Plan what can be seen is that in some places there is a relationship. One of the aspirations in regards to clean air is to meet legally binding targets to reduce emissions of five damaging air pollutants'. ${ }^{136}$ Likewise, in the plan there is reference to bringing forward legislation in regards to emissions from medium sized combustion plants and generators. ${ }^{137}$ There are other cases where the relationship is implicit - for example in regards to the ambition to 'support environmental standards increased from $82 \%$ to $90 \%$ for surface water bodies ${ }^{\text {' }}$ (38 which presumably is indirectly referring to standards in the Water Framework Directive. ${ }^{139}$ But generally, as the EAC noted, there is a "need for a clear line of sight between existing targets, international commitments and the Government's targets'. ${ }^{140}$

${ }^{135} \mathrm{Cl}$ 9(6) and $\mathrm{Cl} 10(3)$.

${ }^{136}$ DEFRA, A Green Future (n 3) 24.

137 ibid 97, 99.

138 ibid 25.

${ }^{139}$ Directive 2000/60/EC of the European Parliament and of the Council of 23 October 2000 establishing a framework for Community action in the field of water policy [2000] OJ L327/1.

${ }^{140}$ EAC, The Government's 25 Year Plan (n 9) 10. 
This lack of an explicit relationship with legislative obligations reflects an ambiguity over the purpose of EIPs. On the one hand, EIPs can be understood as a device to keep government departments on track. They are thus operating in the shadow of legislation and are an aid to ensuring environmental standards are kept in mind. From this perspective they are akin to an internal governmental management strategy and reflect a belt-and-braces approach to environmental administration.

On the other hand, the ambition for EIPs does not appear to be so modest. The expectation is they will by the centrepiece of this new model of green governance and putting them on a statutory footing bolsters their role. ${ }^{141}$ The lack of an explicit relationship with existing environmental laws marginalises legislation. What now appears important is the Plan itself. The 25 Year Plan for example, in the Government's words, 'sets out how we will deliver on this government's long-term aspiration to protect and improve our environment'. ${ }^{142}$

EIPs are not created through a conventional law-making process however. Indeed, they are not created through a law-making process at all. But the Draft Bill elevates them to a central position in environmental law - not just by giving them a statutory footing, but also by making them the benchmark by which action is assessed. Overall, EIPs are seemingly shifting the architecture of environmental protection dramatically away from established legal frameworks.

${ }^{141}$ Government Response (n 57) 1. 142 ibid 1. 


\subsection{Office for Environmental Protection}

The third aspect of the Draft Bill follows through on Section 16(d) of the European Union (Withdrawal) Act 2018, to create and empower a new Office for Environmental Protection (OEP). The European Commission has played an important role in enforcing EU environmental against Member States law through infringement procedures. ${ }^{143}$ The UK has had a number of enforcement actions brought against it including in regards to water quality, ${ }^{144}$ nature conservation, ${ }^{145}$ and access to justice. ${ }^{146}$ Some of these enforcement actions raise straightforward legal issues, but many also raise tricky legal issues about the process and substance of environmental law. ${ }^{147}$ The same is true of judicial review cases that concern the proper implementation of EU law. ${ }^{148}$

The Commission's enforcement role will disappear with leaving the EU. Commentators, while recognising the importance of judicial review, have thus argued the need for something to replace the Commission's enforcement and reporting role. ${ }^{149}$ For

${ }^{143}$ Pål Wennerås, The Enforcement of EC Environmental Law (Oxford: OUP, 2007).

${ }^{144}$ Case C-56/90 Commission v United Kingdom [1993] ECR I-4109.

${ }^{145}$ Case C-6/04 Commission v United Kingdom [2005] ECR I-9017

${ }^{146}$ Case C-530/11 Commission v United Kingdom ECLI:EU:C:2014:67.

${ }^{147}$ Colin Reid and Michael Woods, 'Implementing EC Conservation Law' (2006) 18 JEL 135 discussing Case C-6/04 (n 145).

${ }^{148}$ ClientEarth (No.2) (n 188). For a discussion see Joanna Bell,' ClientEarth (No 2): A Case of Three Legal Dimensions' (2017) 29 JEL 343.

${ }^{149}$ Maria Lee, 'Brexit and Environment Protection' (n 12) 
example, UKELA in a 2017 report made a strong argument for a new supervisory body and provided examples of environmental ombudsmen and courts from around the world. ${ }^{150}$ Independence from government is identified as one the most important features of such a body. ${ }^{151}$

The Draft Bill creates an OEP. ${ }^{152}$ The OEP is not a formally independent body, but clause 12 states that the OEP must 'have regard to the need to act (a) objectively (b) impartially (c) proportionally; and (d) transparently. ${ }^{153}$ The first two of these requirements reflect traditional civil service ideals. None guarantees independence.

The OEP has a number of functions. As noted above it must monitor EIP progress and it also must monitor the implementation of environmental law although there is no prescribed timing for this. ${ }^{154}$ It also has an advice-giving function. ${ }^{155}$ More significantly it has a set of enforcement functions that relate to public bodies 'failing to comply with

${ }^{150}$ UKELA, Brexit and Environmental Law (n 93) 11-20.

${ }^{151}$ Ibid 4, 10, 11 and Maria Lee, 'Brexit and Environment Protection' (n 12) 358.

${ }^{152} \mathrm{Cl} 11$. See also the Schedule which sets out details of membership and powers. A detailed discussion of the OEP can be found in Maria Lee, 'The New Office for Environmental Protection: Scrutinising and Enforcing Environmental Law after Brexit' (SSRN Working Paper, January 8, 2019),https://ssrn.com/abstract=3312296 accessed 18 February 2019.

${ }^{153}$ They must also prepare a strategy that sets out how they will do this $(\mathrm{Cl} 12(3))$.

${ }^{154} \mathrm{Cl} 15$.

${ }^{155} \mathrm{Cl} 16$ 
environmental law'. ${ }^{156}$ This phrase is defined in the Draft Bill as including the following conduct: 'unlawfully failing to take proper account of environmental law when exercising its functions' and 'unlawfully exercising, or failing exercise, any function it has under environmental law'. ${ }^{157}$ Enforcement is triggered by a complaint. ${ }^{158}$ The OEP has discretion to carry out an investigation if 'in its view a complaint 'indicates' that 'a public authority has failed to comply with environmental law' and 'the failure is serious'. 159 'Indicates' suggests that the OEP must make a determination that there has been a serious failure from reading the complaint. It is not enough for the complaint to 'allege'. ${ }^{160}$

The OEP is thus required to make an assessment about 'unlawfulness'. How the OEP will assess 'unlawfulness' is by no means clear, but the presumption seems to be it is relatively straightforward. While the Secretary of State in appointing non-executive members to the OEP must 'have regard to the desirability of the members (between them) having experience of 'law (including international law)' and 'investigatory and enforcement proceedings', ${ }^{161}$ there is no other requirement for the OEP to be staffed by lawyers. In the consultation document DEFRA stated that it was expected that ' $[\mathrm{t}]$ he new

${ }^{156} \mathrm{Cl} 17$.

${ }^{157} \mathrm{Cl} 17(2)$.

${ }^{158} \mathrm{Cl} 18$.

${ }^{159} \mathrm{Cl} 19(1)$.

${ }^{160}$ Compare this requirement with the investigatory powers of the Equality and Human Rights Commission, s 20 of the Equality Act 2006.

${ }^{161}$ Schedule. 
body's legal powers around enforcement of environmental laws... would only be expected to be used rarely, 162

The Draft Bill sets out the enforcement procedure that includes information notices ${ }^{163}$ and decision notices ${ }^{164}$ and can ultimately include a review application to the High Court. ${ }^{165}$ The Draft Bill also requires the OEP to publish a strategy that will 'contain a complaints and enforcement' policy. ${ }^{166}$ In considering that policy the OEP must have 'regard to the particular importance of prioritising cases that it considers have or may have national implications' and cases that relate to 'ongoing or recurrent conduct', 'that relate to conduct that the OEP considers may cause (or has caused) significant damage to the natural environment or to human health' or 'that the OEP considers may raise a point of environmental law of general public importance'. ${ }^{167}$

A question arises about the interrelationship between this process and other accountability processes, in particular judicial review. In the consultation paper it was stated by Gove that ' $[\mathrm{t}]$ he role which has been played in the past by the EU Commission and courts should be filled now by a UK body embedded in the UK's parliamentary

\footnotetext{
162 DEFRA, Consultation Paper (n 16) 25.

${ }^{163} \mathrm{Cl} 22$.

${ }^{164} \mathrm{Cl} 23$.

${ }^{165} \mathrm{Cl} 25$.

${ }^{166} \mathrm{Cl} \mathrm{12(3)(c).}$

${ }^{167} \mathrm{Cl} 12(4)$.
} 
democracy'. ${ }^{168}$ It is not clear whether this is a reference to just the EU courts or the UK courts as well. In the Statement of Impacts accompanying the Draft Bill it is stated that the OEP will be 'expected to lead to a reduction in the number and costs of judicial reviews' ${ }^{169}$ It is recognised that the review function would 'allow for the courts to clarify the law where necessary as a result of the new body initiating judicial review proceedings in serious cases, reducing ambiguities and uncertainties in its interpretation and application'. ${ }^{170}$ The general presumption would thus seem to be that even though the OEP will be used rarely it will replace judicial review as an accountability process. Why that is assumed is not clear.

The exact function of the OEP is difficult to determine. As UKELA highlights, having a range of different accountability mechanisms, not just judicial review, is an important feature of most administrative law systems. ${ }^{171}$ It can thus be argued that the creation of a new accountability mechanism to replace the Commission's enforcement powers, even if it is to be used rarely, is to be welcomed. But the OEP is not a direct replacement. It is not independent. Given the need for any complaint to 'indicate' a breach, it also means that it is unlikely that the OEP will be enforcing in ambiguous and uncertain cases. Moreover, there appears to be hints that it is hoped that the OEP will displace other accountability processes.

${ }^{168}$ DEFRA, Consultation Paper (n 16), Foreword.

${ }^{169}$ DEFRA, Draft Environment (Principles and Governance) Bill: Statement of Impacts (December 2018) 5.

170 ibid.

${ }^{171}$ UKELA, Brexit and Environmental Law (n 93). 


\section{Evaluating the Draft Bill}

A number of concerns emerge from the above analysis. At the very least, the Draft Bill does not appear to deliver an effective form of post-Brexit green governance. More worryingly, the Draft Bill is putting forward a highly 'technical', de-legalised, and executive-dominated vision of environmental law. Before exploring these concerns in more detail, it is important to say something about the challenges in analysing such a proposal at a time like this. This is because identifying those challenges provides some insights into the exact nature of the 'unfrozen' moment that Brexit is.

\subsection{Challenges in Analysis}

I'm acutely aware that the discussion in the last section may have made your eyes glaze over. That reflects an inconvenient truth that in writing about legislation there are no automatic narrative structures and no obvious sets of winners and losers. As a structural endeavour, legislation often encompasses a detailed miscellany that by its very legal nature, 'could' and 'might' apply in a range of different legal futures. This is not made any easier in regards to the Draft Bill, because much of the substance is not in the Draft Bill, but in the policy documents surrounding it, particularly the 25 Year Plan.

That is not the only reason why the Draft Bill is difficult to assess however. Given it is part of the Brexit process, and given the anxiety and uncertainties around that process, it is also difficult to maintain a steady analytical gaze. The need for the Draft Bill is due to the UK leaving the EU and the need to maintain and develop a body of environmental law outside the EU. There are real risks to environmental law created by Brexit. They need to be addressed, and the time limit for addressing them is limited. The desire to act quickly is a strong one. The Draft Bill with its emphasis on setting standards and its rhetoric of accountability can, at times, appear a desirable way forward. At the same time, 
given the EU has loomed large in constitutional law and environment law, attention needs to be paid to how reform reconfigures government structures. ${ }^{172}$

Evaluating the Draft Bill is not made any easier by the ambiguity about its purpose. On the one hand, it is framed as addressing the issues that arise because of Brexit. ${ }^{173}$ The three parts of the Draft Bill are thus directly addressing 'holes' created in environmental law by leaving the EU. On the other hand, the Draft Bill is clearly aiming to be a more ambitious reconfiguration of UK environmental law. DEFRA thus states '[a]t the heart of the Bill are the new foundations it will create for long-term environmental governance and accountability'. ${ }^{174}$ Furthermore, given that the Draft Bill and its documentation refer little to existing environmental law it is hard to determine what the relationship with existing laws and legal processes will be. The exercise of evaluation is not made any easier when there is no easily accessible environmental law past to return to. ${ }^{175}$ Furthermore, DEFRA has made clear that the Draft Bill will be followed by another legislative proposal later in the year although do not articulate what will be in that proposal. Indications can be found in other documentation that it will contain more substantive measures but it is not clear what they will be. ${ }^{176}$

${ }^{172}$ Freedland (n 98).

${ }^{173}$ Explanatory Memorandum [29], DEFRA, Consultation Paper (n 16) 24.

${ }^{174}$ DEFRA, Environmental Bill: Policy Paper (n 7).

175 c.f Pontin (n 12).

${ }^{176}$ DEFRA, 'Government Sets Out Plans to Overhaul Waste System' (Press Release 18 February 2019). 
I raise all this, because it is easy to underestimate the analytical difficulties involved in assessing the public law consequences of Brexit. But they are scholarly troubles that need to be confronted if we are truly to make sense of the legal times we find ourselves in. I have no simple solutions to these quandaries, except that public law scholars need to be talking about them.

\subsection{An Ineffective Framework}

While the Draft Bill may not be easy to evaluate, it is not impossible to assess. Even understood at its most innocuous, the Draft Bill is a matter of concern. This is because, as the analysis in the last section highlights, it risks creating a framework that is ineffectual in addressing the lacunas that Brexit will lead to in environmental law.

The Draft Bill does not create any legislative obligation to protect the environment. Rather, it vests significant power in the Secretary of State and other Ministers in regards to policy statements on environmental principles, explicitly stating they need not exercise those powers if there are 'no significant environmental benefits' in regards to formulating and applying those policy statements. ${ }^{177}$ Furthermore, the legal dynamism of the environmental principles in the TFEU and Aarhus Convention is replaced with policy statements on environmental principles that only apply to Ministers in policy-making if certain requirements are met.

The Draft Bill does not also place any limitations on what form an EIP must take. The NCC has been critical of the Bill because it does not place actual targets on a statutory basis and as such 'does not go far enough to secure the improved environment to which

${ }^{177} \mathrm{Cl} 1(5), \mathrm{Cl} 4(2)$ 
the government is committed' ${ }^{178}$ There is no obvious relationship between EIPs and existing legislation. There is also no general duty to review the implementation of legislative obligations. Rather EIPs, as executive plans, are the benchmarks by which progress is assessed by.

The independent European Commission is replaced with a non-independent OEP which has many different limitations on its power which raise genuine questions about how meaningful an accountability institution it can be. ${ }^{179}$ These limitations relate to its reporting and enforcement functions. They also are derived from its institutional capacity.

There are workarounds for all these problems. The courts could apply environmental principles in judicial review of decision-making. ${ }^{180}$ EIPs may simply become redundant if other legislative reforms contain more substantive obligations. The OEP could report on the implementation of legislative obligations. Other accountability mechanisms could be used. It is also entirely possible that the legislative proposal that will follow this Draft Bill may rectify some of these problems. But overall, as currently presented, the Draft Bill fails to address the problems created for UK environmental law by Brexit.

${ }^{178} \mathrm{NCC}$ (n 61) 17.

${ }^{179}$ Maria Lee, 'The Next Generation of Environmental Law' (n 12).

${ }^{180}$ Fishermen and Friends of the Sea $v$ The Minister of Planning, Housing and the Environment (Trinidad and Tobago) [2017] UKPC 37. 


\subsection{A Concerning Vision of Post-Brexit Environmental Law}

This is not the only, or the most significant issue, with the Draft Bill however. The Draft Bill also lays the foundations for a new architecture for environmental law in the UK one that goes beyond addressing the legal deficits that Brexit will create. That architecture has three features - it is executive dominated, de-legalised, and downplays the importance of public reason.

As Elliott and Tierney note in their analysis of the European Union (Withdrawal) Act 2018,

[t]he Brexit story so far thus reveals an old truth about the British constitution: that while executive authority is in principle rightly limited by law... the true limits of executive authority are in the gift of a Parliament whose legal capacity to vest power in the executive is unlimited. ${ }^{181}$

The Draft Bill if it were to become legislation, would be a perfect example of that. Its provisions concerning environmental principles and EIPs entrust the Secretary of State with the process of defining the norms and baselines for environmental decision-making. Moreover, the Draft Bill also creates an enforcement function which is not independent from the executive, but is hoped to play a significant role in enforcement. Likewise, the annual reports on EIP progress to Parliament are understood as a major source of accountability but produced by DEFRA itself. In the EAC's terms, these accountability mechanisms become dangerously close to the government 'marking its own

${ }^{181}$ Elliott and Tierney (n 15) 59. 
homework'. ${ }^{182}$ This new architecture is the architecture of an environmental law dominated by the executive.

Furthermore, a striking feature of the Draft Bill is that this domination is not through delegated legislation, or even Henry VIII clauses. It is through elevating the status of particular types of administrative guidance - policy statements and EIPs - that are not created through any law-making process. Legislative obligations are seemingly sidelined. Legal enforcement is cast as a relatively straightforward exercise. Policy and administrative guidance have always been a feature of English planning law and environmental regulation. ${ }^{183}$ Environmental programmes have been a feature of EU environmental law. ${ }^{184}$ But this Bill elevates policy to a new level of authority. Overall, the architecture of this Bill presents a de-legalised vision of environmental law. By that, I mean it is paradoxically, 'maximally free from the impediment of law'. ${ }^{185}$

That vision is not only de-legalised however. It is also a highly 'technical one' in which public reason is deemphasised. To understand that we need to return to the 25 Year Plan. The plan defines targets and frames accountability in regards to those targets. This is a very simplified vision of environmental law. There is none of the normal stuff of

${ }^{182}$ EAC, The Government's 25 Year Plan (n 9) 18.

${ }^{183}$ Laurence Etherington, “"Mandatory Guidance” for Dealing with Contaminated Land: Paradox or Pragmatism?' (2002) 23 Statute Law Rev 203 and William Upton QC, 'What is the Purpose of Planning Policy? Reflections on the Revised National Planning Policy Framework 2018' (2019) 31 JEL (advance access).

${ }^{184}$ Article 191(3) TFEU.

${ }^{185}$ Keith Werhan, 'Delegalizing Administrative Law' [1996] Illinois L Rev 423460 
environmental law - the challenges in defining waste, ${ }^{186}$ the difficulties of deciding whether an assessment of environmental impacts is needed, ${ }^{187}$ or the complex questions that arise in the creation of plans to address an issue such as air quality. ${ }^{188}$ The public and their concerns are also out of the picture. ${ }^{189}$ Again, as this is a policy, that is perhaps not surprising. But given the emphasis on 'action' the absence of the complexities of the subject is striking.

Overall, this vision of environmental law appears to require only a change to technique and 'demanding little or nothing in the way of change in human values or ideas of morality'. ${ }^{190}$ Targets are being pursued through measurable indicators and there is little discussion how those targets will be substantively met. Environmental law is being closed off from discussion and public reason. ${ }^{191}$ The NCC and EAC have raised concerns about

${ }^{186}$ Eloise Scotford, 'Trash or Treasure: Policy Tensions in EC Waste Regulation' (2007) 19 JEL 367.

${ }^{187}$ Kalina Arabadjieva, 'Vagueness and Discretion in the Scope of the EIA Directive' (2017) 29 JEL 417.

${ }^{188}$ ClientEarth (No.2) v Secretary of State for the Environment, Food and Rural Affairs [2016] EWHC 2740 (Admin).

189 Chiara Armeni, 'Participation in Environmental Decision-making: Reflecting on Planning and Community Benefits for Major Wind Farms' (2016) 28 JEL 415.

${ }^{190}$ Hardin (n 19) 1243. See Elizabeth Fisher, 'Imagining Technology and Environmental Law' in Roger Brownsword, Eloise Scotford, and Karen Yeung (eds), Oxford Handbook of Law, Regulation and Technology (Oxford: OUP, 2017).

191 Theodore Porter, 'How Science Became Technical' (2009) 100 Isis 292 
whether the 25 Year Plan is actually a meaningful template for delivering environmental protection. ${ }^{192}$ Thus, the NCC highlights that some of the accompanying documentation concerning proposed indicators is problematic as there is 'little knowledge of whether the method to achieve the outcomes could result in further degradation of the environment in other areas' ${ }^{193}$ The EAC has raised concerns about too great a focus on natural capital. As they note, 'legal protections cannot be replaced with an economic valuation'. ${ }^{194}$ All of this reflects that while targets have the appeal of precision, '[p]recision is the quality of being definite and unambiguous, which need not signify correctness' ${ }^{195}$

There is a further irony. One of the common British criticisms of EU environmental law has been it is a rigid model of regulation that sits uneasily with the flexible British common law tradition. ${ }^{196}$ Whatever may be the fairness of this criticism, what is not in doubt is that the Draft Bill's vision of governance is far more technical than anything found in EU environmental law. EU environmental law has always involved a variety of different Member State and EU institutions, and the case law that has emerged reflects this. ${ }^{197}$ The norms and mandates of EU environmental law may be more explicit than was historically the case in the UK, but a single institution has never been responsible

${ }^{192}$ NCC (n 61) and EAC, The Government's 25 Year Plan (n 9).

${ }^{193}$ NCC (n 61) 16.

${ }^{194}$ EAC, The Government's 25 Year Plan (n 9) 47.

195 Theodore Porter, 'Speaking Precision to Power: The Modern Political Role of Social Science' (2006) 73 Social Research: An International Quarterly 1273, 1280.

${ }^{196}$ See these accounts in Pontin (n 12) 8, 13, 22, 59.

${ }^{197}$ Scotford (n 48) Ch 4. 
for determining what they are. In contrast, the Draft Bill centralises environmental law around a singule paradigm.

\section{A Constructive Way Forwards}

It is, of course, easy to criticise a legislative proposal for not being what you want it to be. But my argument is not the Draft Bill is not to my liking or does not accord with utopian visions of environmental law. Rather, and this is particularly obvious when compared to other discussions about environmental law (see section 1.3), the Draft Bill is disconnected from the physical, socio-political, and legal realities that a study of environmental law as embedded in legal cultures immediately reveals. Specifically, the Draft Bill does not engage with the nature of environmental problems, why legislation is so valuable, and the fundamental importance of any action being consistent with British constitutionalism. In considering each of these in turn, I provide some touchstones in thinking about how to move forwards either in regards to this legislative proposal or to UK environmental law more generally.

\subsection{Environmental Problems}

Missing from the Draft Bill or the 25 Plan is any detailed discussion of the nature of environmental problems. Yet that nature needs to inform any process of law reform. As noted in Section 1, environmental problems are contentious. Democratic communities are invariably pro-environmental protection, but what this means in specific circumstances is often controversial as it requires individuals to adjust their behaviour, often in significant ways. This is why, for example, achieving clean air has been so challenging ${ }^{198}$ and climate

${ }^{198}$ ClientEarth [2015] UKSC 28 (n 47); ClientEarth (No.2) (n 188); Clientearth, R (On the Application Of) v Secretary of State for Environment, Food And Rural Affairs [2017] 
change has become such a significant fault-line in politics. ${ }^{199}$ A fundamental feature of environmental law is that it is a framework for legitimately managing these conflicts through a range of law-making, administrative, and adjudicative processes. Short-term winners and losers will have to be chosen and that needs to be done fairly and legitimately. The end result in a thick body of law that stabilises in light of the legal disruption created by environmental problems and the responses to those problems. ${ }^{200}$

Reading the DEFRA documentation gives a different impression however. The starting assumption in the Conservative Manifesto's aim to be 'the first generation to leave the natural environment in a better state that that in which we found it' is not grounded in any analysis of why previous generations failed to do this. ${ }^{201}$ Rather, what is presented is a highly technical model of environmental governance in which law appears to have little role to play.

The lack of engagement with the substantive nature of environmental law, and its successes and its failures means that the Bill is not grounded in an understanding of the type of challenges that the complexity of environmental problems creates for developing and maintaining a robust body of law. It is not just that environmental problems are

EWHC B12 (Admin); and Clientearth No.3, R (on the application of) v Secretary of State for Environment, Food and Rural Affairs [2018] EWHC 315 (Admin) (21 February 2018) ${ }^{199}$ Latour, Down to Earth (n 78). Note climate change is largely an excluded matter: Cl 31(3)(a).

${ }^{200}$ Fisher, Scotford and Barritt (n 25) and Elizabeth Fisher, 'Law and Energy Transitions: Wind Turbines and Planning Law in the UK ' (2018) 38 OJLS 528.

${ }^{201}$ Cf DEFRA, A Green Future (n 3) 21-2. 
polycentric and we have limited scientific knowledge about them, but that these features of environmental law are structural features of the subject. ${ }^{202}$ Much of the reasoning in environmental law involves these structural features. This is why the precautionary principle, which focuses on scientific uncertainty, has been controversial and given rise to such a rich body of case law. ${ }^{203}$ It is also why there has been a concern to adapt adjudication so it can address environmental problems. ${ }^{204}$ More significantly, the richness of legal reasoning and legal doctrines accommodates different law-making initiatives over time, and the competing views that exist in regards to an environmental law problem. ${ }^{205}$ My point is not that law is perfect at doing these things, but given the complexity of environmental law, the substantive nature of law has an important 'law job' to play. ${ }^{206}$ In contrast, the Draft Bill offers up a vision of environmental law in which environmental quality is achieved through policy statements and target setting.

A response to the above may be that the Draft Bill is not removing other legislation so these concerns are overstated. Day-to-day environmental law will continue its business as usual. The Draft Bill may not be 'the robust new system of green governance' 207 that

${ }^{202}$ Elizabeth Fisher, 'Environmental Law as 'Hot' Law' (2013) 25 JEL 347

${ }^{203}$ Elizabeth Fisher, Risk Regulation and Administrative Constitutionalism (Oxford: Hart Publishing 2007) Chs 4, 6.

${ }^{204}$ Ceri Warnock, 'Reconceptualising Specialist Environment Courts and Tribunals' (2017) 37 Legal Studies 391

${ }^{205}$ Latour (n 30).

${ }^{206}$ Pontin (n 12) 20-22 developing the term from the work of Karl Llewelyn.

${ }^{207}$ DEFRA, Draft Environment (Principles and Governance) Bill (n 5)3. 
DEFRA asserts it to be. All these points are fair to raise. But given that the Draft Bill is presented as a new architecture for environmental law, its vision of environmental governance is a matter for concern, particularly when the EIP is understood as the agent of change. As noted above, there is little regard for what such change will involve. A target by itself is not enough to make change, and the process of change raises the need for readjustment and much else besides thus directly engaging the messy substantive nature of environmental law.

\subsection{Environmental Legislation}

The Statement of Impacts accompanying the Draft Bill states that the Draft Bill 'will create no direct impacts on business' and 'the measure will have no distributional impacts' ${ }^{208}$ There is of course a truth to these assertions. The Draft Bill will not have those impacts because the Draft Bill itself is an empty framework. It contains no substantive legislative standards for protecting the environment. It is does not legislate norms and it does not set mandates. It is in short, not a meaningful form of legislation.

As already noted, legislation is fundamental to environmental law as a way of collectively addressing collective action problems. In addressing those problems, legislation frames our understanding of the natural environment and how and why we value it. It empowers, it limits, and it demarcates. Legislating is an authoritative act of framing. Legislating dictates what is deemed relevant and not relevant, what requires protection and what does not, and what power is vested in administrative institutions and what power is not.

${ }^{208}$ DEFRA, Statement of Impacts (n 169) 9. 
All these things are significant exercises of state authority. They should be done with thought and care. ${ }^{209}$ An important virtue of doing these things through legislation is that, as the legal philosopher Jeremy Waldron notes, legislating is 'making or changing law explicitly through a process and in an institution publicly dedicated to that task' ${ }^{210}$ That process as Waldron also states is 'not the same as issuing a decree; it is a formally defined act consisting of a laborious process'. ${ }^{211}$ Such a legislative process is grounded in a duty to legislate carefully and to deliberate. ${ }^{212}$ Legislatures in doing these things know there is disagreement and that the legislative process must navigate those disagreements to produce a legal text. As large assemblies, legislatures are 'structured in a way that represents (or claims to represent) the more serious and substantial disagreements that there are in a society about the way in which society is organised'. ${ }^{213}$

Moreover, given the formal nature of this process, legislation can provide an important source of stability and 'calculability' ${ }^{214}$ Actors in the legislative process know they are producing law, and that legislative reform will take time. This stability not only accords with rule of law ideals about legal certainty, but is also important in making markets work. As the sociologist Neil Fligstein notes '[m]arkets are...characterised by

209 Jeremy Waldron, 'Thoughtfulness and the Rule of Law' (2011) 18 British Academy $\operatorname{Rev} 1$.

${ }^{210}$ Jeremy Waldron, Political Political Theory (Cambridge: Harvard UP, 2016) 154.

211 See also Waldron, The Rule of Law (n 21) 107.

212 Jeremy Waldron, Law and Disagreement (Oxford: Clarendon Press, 1999) 69-80.

213 ibid, 23.

${ }^{214}$ Waldron, The Rule of Law (n 21) 53. 
structured exchange'215 and the calculability provided by legislation encourages that structured exchange. Thus, for example, in the climate change sphere, the clarity provided by the clear obligations of the Climate Change Act 2008 and Section 32 of the Electricity Act 1989 (and obligations in EU law) have been important in aiding the energy transition in the UK. ${ }^{216}$ Legislation does this, because although it can be changed, the process by which it can be changed is clear.

In contrast, the process of creating policy statements on principles and EIPs, are not subject to these deliberative processes at all. They can be changed through processes that do not involve a wider polity. As the text of the 25 Year Plan illustrates, there is also a chance that the text does not create easy calculability. The Draft Bill thus easily falls far below what should be expected of legislation.

Stressing the importance of meaningful legislation is not to make an argument against courts or administration. As highlighted in Section 1, there is an essential role to be played by both in environmental law. But legislation does have a particularly important role in delineating the mandates, norms and architecture of environmental law. Legislation in this regard is a 'structural endeavour'. ${ }^{217}$ and almost akin to a constitution

${ }^{215}$ Neil Fligstein, The Architecture of Markets: An Economic Sociology of Twenty Frist Century Capitalist Societies (Princeton: Princeton UP, 2001) 30.

${ }^{216}$ Fisher, 'Law and Energy Transitions' (n 200).

${ }^{217}$ Douglas Kysar, 'Global Environmental Constitutionalism: Getting There from Here' (2012) 1 Transnational Environmental Law 83, 90. 
that coordinates debate and action within government. ${ }^{218}$ Legislation, particularly environmental legislation harnesses the institutional capacity of the separation of powers. Given the complexity of environmental problems that is particularly important as all three arms of government need to be mobilised.

\subsection{British Constitutionalism}

Highlighting this also highlights that the Draft Bill is not just problematic as a form of legislation. The executive-dominated architecture it creates also does not sit easily with principles of British constitutionalism. Returning to Elliott and Tierney, while they do note that 'the true limits of executive authority are in the gift of parliament', they also note ' $[\mathrm{w}]$ ith great power goes great responsibility — including a responsibility to legislate in a way that is faithful to the requirements of constitutional principle and that ensures executive accountability'. ${ }^{219}$ In other words, British constitutional law needs to frame what is possible.

Stating this is not to put forward a monolithic understanding of constitutional law. British constitutional principles are contested. ${ }^{220}$ Nor is it saying that forms of rationalisation and experimentation are not possible. Constitutionalism evolves. What it is saying is that in a process of law reform such as this, law and constitutional principle must be the starting point. In the process of evolution, it must be kept in mind that law

${ }^{218}$ Elizabeth Fisher, 'Towards Environmental Constitutionalism: A Different Vision of the Resource Management Act 1991' [2015] Resource Management Theory and Practice 63

${ }^{219}$ Elliott and Tierney (n 15) 59.

${ }^{220}$ Adam Tomkins, Public Law (Oxford: Clarendon Press, 2003). 
has a 'homeostatic quality which is produced by the obligation to keep the fragile tissue of rules and texts intact'. ${ }^{221}$ Likewise, there needs to be general recognition of the importance of the different institutions of government. ${ }^{222}$ As Freedland has noted these ideas amount to a concept of sustainable governance grounded on a 'constitutional substratum' which is 'a deep layer of public arrangements or institutions which need to remain in a steady and workable state if the high and visible pinnacles of the constitutional landscape are themselves to stand intact' ${ }^{223}$

The significant and the novel power that the Draft Bill vests in the Secretary of State sits uneasily with that substratum. The Draft Bill vests he or she with powers to articulate and elaborate upon the norms and aspirations of environmental laws in ways alien to normal constitutional practices. The executive is a major player in the legislative process, but the Draft Bill replaces those legislative processes with policy processes processes in which there are few precedents for parliamentary influence. ${ }^{224}$ The role of courts is not only side-lined in this new architecture, but also made quite ambiguous. Furthermore, there is very little discussion of British institutions of state and there is no reference to the common-law tradition. This is indeed, a disembedded model of governance. The 'unfrozen moment' of Brexit may be producing a new and 'world-

\footnotetext{
${ }^{221}$ Latour (n 30) 242-3.

222 ibid.

${ }^{223}$ Freedland (n 98) 6.

${ }^{224}$ For a discussion of parliamentary influence in the legislative process, see Meg Russell and Daniel Gover, Legislation at Westminster (Oxford: OUP, 2017).
} 
leading' vision of environmental law, but it is one that has no easy relationship to British concepts of constitutionalism.

\section{Conclusion}

Much intellectual and political energy of the last three years has been spent on the Brexit process. But lawyers and legal scholars also need to turn their attention to the architecture of the post-Brexit futures that are now being proposed. I do not pretend that giving and maintaining that attention is easy. There is much else going on. Legislation is hard to evaluate. The need for reform is urgent. These proposals can be novel. The yardsticks for evaluation are difficult to determine - are proposals merely patching up the legal holes created by Brexit or are they dramatic acts of re-imagination? But what this article has shown is that these proposals should not be ignored.

The Draft Environment (Principles and Governance) Bill may only be at the prelegislative stage, but there are serious concerns about how effective it will be in addressing the gaps in environmental law left by Brexit. The potential vision of environmental law it presents is also a worry for environmental lawyers and public lawyers due to it being so executive-dominated, delegalized, and technical. While the 'unfrozen moment' of Brexit is a time of 'new possibilities', that does not mean that anything is possible. In moving forward in the environmental law context there needs to a focus on understanding of environmental problems and the role of legislation and constitutionalism in addressing those problems. Or to put the matter another way, now more than ever, it is important to prioritise a robust understanding of UK legal culture and UK constitutionalism. 


\section{Postscript - 7 May 2019}

In late April 2019, the EAC and the House of Commons Environment, Food and Rural Affairs Committee (EFRAC) both published critical and detailed reports scrutinising the Draft Bill. ${ }^{225}$ Both reports highlight the inadequacies the Bill compared to current legal frameworks. ${ }^{226}$ Both contain a thorough examination of provisions of the Bill. Both reports also note the genuine difficulties in assessing the Bill given that it forms part of a larger package of yet unknown legislative reform. ${ }^{27}$ The Environment, Food and Rural Affairs Committee stress the need, in light of this, for there to be proper scrutiny by it of the full Bill as part the legislative process. ${ }^{228}$ As both committees also underscore, this process of legislative reform really matters - it is important 'to get it right'. ${ }^{229}$ As this article has shown, that is not only in regards to ensuring the environmental law gaps left by EU membership are addressed, but also that the future model of environmental law 'governance' is a legally and constitutionally robust one.

${ }^{225}$ EAC, Scrutiny of the Draft Environment (Principles and Governance) Bill (HC 1951, 2019) and EFRAC, Pre-Legislative Scrutiny of the Draft Environment (Principles and Governance) Bill (HC 1893, 2019).

${ }^{226}$ EAC, Scrutiny (n 225) 3-5 and EFRAC (n 225) 3.

${ }^{227}$ EAC, Scrutiny (n 225) 3 and EFRAC (n 225) 52.

${ }^{228}$ EFRAC (n 225) 7, 52.

${ }^{229}$ ibid 3. 
